Article

\title{
Identity, Power, and the California Welfare-Rights Struggle, 1963-1975
}

\author{
Allison Puglisi \\ Program in American Studies, Harvard University, Cambridge, MA 02138, USA allisonpuglisi@g.harvard.edu \\ Academic Editor: Annabel Martín \\ Received: 14 February 2017; Accepted: 29 March 2017; Published: 2 April 2017
}

\begin{abstract}
This article explores the work of welfare-rights activists in 1960s and 70s California. These activists were mostly working-class black and some white mothers, and the majority of them were themselves welfare recipients. As welfare recipients, women of color, and working-class people, they faced a wave of policies and ideologies that stigmatized them, policed their behavior, and made receiving benefits increasingly difficult. These policies were but one element of a larger political crisis, wherein the California government stoked racialized and gendered fears in order to shrink the welfare state. Rather than simply acquiesce to this reality, welfare-rights groups in California refused to accept it. Though scholars have studied welfare-rights groups in Washington, D.C., Nevada, New York, and other US states, almost no attention has been given to groups in California. In this article I use state legislation, newspaper articles, organizational records, and archived interviews to illustrate how California's welfare-rights movement challenged anti-welfare policy and ideology. I argue that they did more than simply reject punitive legislation. They emphasized childcare, rebuked middle-class complacency, questioned the primacy of the nuclear family, and dismissed gender roles. In the process, they raised crucial, enduring questions about the nature of economic-justice organizing.
\end{abstract}

Keywords: race; feminism; welfare reform; Reaganism; organizing

\section{Introduction: Welfare Recipients Organize in California}

In 1963, Johnnie Tillmon — a black single mother on welfare-decided to get in touch with fellow welfare recipients in Los Angeles. She was tired of enduring the stigma that came with being on welfare- and she did not want to endure it alone. She envisioned a group of welfare recipients that would support one another, exchange advice, and even pressure the California government for policy changes. In putting this group together, the first step was to find out who else was on welfare, or Aid to Families with Dependent Children (AFDC). "That was a hard job", said Tillmon, "because that kind of information was not made public. We were in the housing project manager's office one day when he was called to the phone. Instead of taking the call in his office, he took it from outside. While he was out, we started looking through the papers on his desk." Among those papers was a list of neighborhood welfare recipients, and Tillmon "copied the names". Soon after, she went door-to-door, spoke with neighbors in her housing project, and a group of welfare recipients began to form. This group came to be called Aid to Needy Children-Mothers Anonymous ([1], p. 18), or ANC-MA: one of many local welfare-rights groups across the country.

Historians Sherna Gluck, Felicia Kornbluh, Premilla Nadasen, and Annelise Orleck are known for their work on the welfare-rights movement. They have explored the movement in Nevada, New York, and Washington, D.C. Here, I build on their valuable research with a study of California. California is indispensible to the welfare-rights story for a number of reasons. It was home to over 50 local welfare-rights groups [2]; more importantly, California can be understood as a testing ground for the policies and ideologies that then-Governor Ronald Reagan would later propagate as US president. 
Finally, California activists lent momentum and leadership to the broader, nationwide movement for welfare rights. In 1966 - three years after ANC-MA's founding-welfare recipients built a national group: the National Welfare Rights Organization (NWRO). The NWRO used lobbying and direct action to pursue a three-pronged agenda: a "guaranteed annual income", an increase in "availability of welfare benefits and services", and improved "access to consumer credit ([3], p. 301)." Johnnie Tillmon was selected to serve as the NWRO's chair, bringing with her the knowledge and experience she had gained in California.

Across California, welfare-rights activism grew organically: in living rooms and churches. It organized in direct opposition to the language and policies of Governor Ronald Reagan, the California legislature, bigoted social workers, and even middle-class black and feminist communities. It formed local organizations, including Tillmon's ANC-MA, the California Welfare Rights Organization (CWRO), and many others. I explore the work of those organizations using legislation, newspaper articles, organizational records, and archived interviews. I argue that to challenge anti-welfare policy and ideology, these activists emphasized childcare, rebuked black middle-class complacency, questioned the primacy of the nuclear family, and dismissed gender roles. I begin by introducing Johnnie Tillmon and other welfare-rights activists. I continue with a discussion of the racialized and gendered policy and ideology these women faced. Finally, I explore how their responses to this climate challenged not just punitive legislation but broader cultural assumptions about class, race, family structure, and gender.

Johnnie Tillmon was born in the rural town of Scott, Arkansas, where she sharecropped and laundered clothing. In 1960, she gathered her children and left an unfaithful husband for Watts, California ([4], p. 28). Tillmon did not encounter welfare politics until 1963, when she became severely ill. Realizing that she could no longer adequately support her family, she decided to apply for welfare ([4], p. 28). To her surprise, she encountered a system almost as degrading as her sharecropping work. She learned that officials could inspect her home without permission, and they would drop her from the welfare rolls if they found evidence of a man's presence ([4], p. 29). Refusing to tolerate this treatment, she decided to organize other welfare recipients.

Assembling a welfare-rights movement was difficult. It was not like race-based organizing: organizers could not tell who was on welfare by looking, and many kept their recipient status a secret out of shame. Dee Johnson, for example, was living in Nickerson Garden Housing project in Los Angeles when Johnnie Tillmon came to her door, inviting her to a welfare-rights meeting. She lied to Tillmon, saying she was not on welfare and was not interested in joining the group. Tillmon knew Johnson was lying, because "she had been to the office and got all the names of the welfare recipients [5]" - and Johnson was on the list. "I didn't want to be associated with the welfare department", Johnson said. "You know people on welfare-I didn't want my friends to know that I was gettin' welfare." In time, though, she began going to meetings [5]. When Tillmon visited their homes, women like Johnson began to realize that the gains of organizing far outweighed the consequences of stigma. Soon these women were known as Aid to Needy Children-Mothers Anonymous (ANC-MA).

The main purpose of ANC-MA was to provide a support network for welfare recipients-and to intervene where the welfare state had failed them. In August of 1963, ANC-MA set up a physical office in Watts, where welfare recipients counseled one another. They "helped people who had been cut off assistance, who had not gotten a grocery order, or with other similar welfare problems ([6], p. 20)". By exchanging information and advice, welfare recipients could prepare each other for conversations with social workers, private investigators, and government officials. ANC-MA also hosted seminars on state policies. In October 1971, for example, Tillmon and other ANC Mothers organized a seminar on "prepaid medical programs in the state of California" so low-income people could know their healthcare options. Over 200 people attended the seminar [7]. With the help of seminars like these, recipients could sift through legal language and learn how new policies would impact them.

In Northern California, meanwhile, others were beginning to organize. Espanola Jackson, a black mother in Bayview-Hunters Point, stumbled upon welfare-rights activism almost by accident. In 1966, 
she was driving with a friend to the local welfare office when she met some welfare-rights activists tabling nearby. Jackson had only been on AFDC for a year, and she wanted to learn more about her rights [8]. At the time, she was receiving very small monthly checks: just over three hundred dollars for her and six children. Feminist author Guida West asked her how she could live on so little. "You really wasn't living", Jackson answered. "You really were just existing." This came with serious implications for her children, who were

sleeping on a bare mattress. I didn't have any plates for all of my children to eat out of. They would have to wait until two or three got finished and then the others would eat. And I didn't have a kitchen table. I had one high chair and my baby sat in the high chair and my children were eating on the floor. I put newspaper on the floor and they would sitting [sic] on the floor eating. So when people talk about hard times you have hard times on welfare and if anyone thinks that people have made it they need to get on welfare themselves and really see. We didn't eve [sic] have toilet paper [8].

Jackson's difficult experiences as a welfare recipient motivated her to join the welfare-rights struggle-and eventually, she rose to leadership positions. She became chair of the Bayview- Hunters Point Welfare Rights Group. In that position, her job was to "go and speak to the Commission and let them know that we wasn't getting the things that we were entitled to [8]". Note that Jackson wrests the term "entitled" from its often negative connotations of self-indulgence and self-importance. Here, "entitled" has a more positive charge of dignity and deservedness. To Jackson, then, welfare was clearly more like a paycheck than a so-called "handout". In fact, her words suggest she negotiated welfare with state officials much like a labor union would negotiate wages with an employer. In conceiving of welfare like a wage, Jackson rejected the racialized discourse of laziness and dependency so often placed onto the individual lives and families of welfare recipients.

Many welfare recipients had internalized that discourse over years and decades; it did not dissipate easily. Moice Palladino, a divorced white mother from San Francisco, faced deep hostility from her ex-husband's family when she subscribed to AFDC and joined the welfare rights movement. "When I was most active in welfare rights", said Palladino, "my mother-in-law would cut pictures of me out of the paper and send it back east" to Palladino's ex-husband-just "to show what a terrible person I was and how I was embarrassing the family". Initially Palladino felt "there was something wrong with her as a person" but decided not to let anti-welfare messaging stifle her organizing. Palladino helped to run the San Francisco Welfare Rights Council, and in 1969, she became involved in a statewide welfare-rights group: the California Welfare Rights Organization (CWRO). She later served as vice president of the CWRO alongside the organization's president: a black feminist named Catherine Jermany [9].

The CWRO, led by Jermany and Palladino, was a statewide umbrella organization to which smaller groups-like the ANC-MA or San Francisco Welfare Rights Council-would report their successes and challenges. The CWRO also launched campaigns against policies they felt were damaging to welfare recipients. In 1971, for example, the CWRO launched a "ZAP FAP" campaign to defeat the Family Assistance Plan (FAP), a federal program proposed by President Nixon. Its stated purpose was to guarantee a minimum income to all families who had satisfied certain work and other requirements. Under this plan, the most a family could receive was $\$ 2400$ ([10], p. 605). In 1971, FAP had just passed in the House-and members of the CWRO were lobbying the Senate to vote no. At first glance, FAP might have seemed promising, but once welfare-rights activists learned it would entail cutting aid to seniors, blind people, and others with disabilities [11], they resolved to "ZAP FAP". This approach exemplified coalitional politics. It did not matter if a guaranteed minimum income would offer some small improvement in aid for a subset of their members. Welfare recipients did not want this aid at the cost of another group. Able-bodied and disabled recipients were pitted against each other in the very writing of FAP. As the FAP story shows, legislative politics often tempted activists to polarize by identity and foreground one group's needs in the interest of political expediency: something welfare-rights activists refused to do. 
What united all of these welfare-rights groups—whether local, citywide, or statewide-was the fundamental notion of welfare as a right. One member of the CWRO assembly, John Burton, told the other members:

It is the responsibility of the society to provide jobs for those who desire to work and have the physical and mental capabilities. There is no one I know who is on welfare who wants to be on it. The government has the responsibility to provide ways for people who want to and are able to get off the welfare and to provide dignity for all recipients. Other groups in the society receive welfare, only for them it is called a subsidy. Oil allowances, banks, railroad, and other major industries are given these subsidies. When recipients are given these allotments by the government, it is called welfare [12].

If corporate interests could receive welfare, these activists reasoned, so should low-income Americans.

\section{Racialized and Gendered Legislation}

Comprehensive welfare in the United States began with Aid to Dependent Children (ADC), a program established under the Social Security Act of 1935. ADC gave a "small monthly allowance for children and nothing for the mother ([6], p. 4)". By giving money exclusively to children, the federal government signaled its distrust of the adult poor and established welfare as a resource for circumstantial, "undeserved" poverty. ADC also concretized household gender roles in that it "followed directly from the American family ideal of a breadwinning husband and a domestic wife-if the husband was absent, the state would step in to take his place in the support of mother and children ([13], p. 14)". By this logic, married or working mothers had no valid claim to welfare benefits. For this reason, black mothers-who, unlike their white counterparts, had long worked outside the home- either had to leave their jobs, or work in secret and risk being dropped from the welfare rolls.

It was not until 1962 that Aid to Dependent Children became Aid to Families with Dependent Children (AFDC) ([14], p. 31). AFDC was similar to its predecessor in that it was carried out by individual states and still aimed to enforce traditional gender roles, but now served families ([15], p. 279). Under AFDC, welfare recipients were heavily policed. In many states, they were subject to "employable mother" laws, which "required all able-bodied mothers to work when 'suitable work' was available"; other laws disqualified welfare recipients who had children out of wedlock ([16], p. 266).

When ADC became AFDC, a number of politicians and social scientists offered their theories on welfare, poverty, and family structure. They were primarily concerned with black women and families, despite the fact that just over half of all women on welfare were white ([17], p. 144). Senator Patrick Moynihan's famous 1965 report, The Negro Family, blamed black matriarchy for men's unemployment. Black families, Moynihan argued, were marked by domineering wives and subordinate or altogether absent husbands ([18], pp. 63-64). In sum, Moynihan saw black women's leadership not as one legitimate way to run a family, but as a self-inflicted predicament-and a deliberate, even malicious, attempt to emasculate breadwinning men.

ADC, AFDC, and the Moynihan Report helped to shape local policies and narratives. Governor Reagan's California was particularly averse to the notion of welfare, let alone welfare rights-so Tillmon, Johnson, Jermany, and other activists had a huge task ahead. Across California, a practice called Operation Weekend, Reaganist political ideology, and the Welfare Reform Act of 1971 all helped to further the notion that black women's poverty did not deserve public assistance.

Beginning in 1962, Kern County of California, like many other counties across the nation, adopted a practice known as "Operation Weekend": investigators, hired by social workers, would enter welfare recipients' homes unexpectedly and at unusual hours to ensure their behavior merited public aid. After Kern took up Operation Weekend, other counties followed ([4], p. 29), and soon the practice of late-night raids became nearly statewide. Social workers claimed that the purpose of these raids was to ensure compliance with state and federal regulations. Such regulations, however, were simultaneously racialized, gendered, and classed. With each visit, recipients were forced to verify "their 
destitution, and, increasingly, their willingness but inability to work ([6], pp. 12-13)". Unlike their white counterparts, women of color had long been pressured to work outside the home: only under extreme circumstances could they be exempted. Recipients were also forced to verify their single status. The raids all tended to take the same format: "One [investigator] was at the back door and one was at the front door. The knock came from the front door. You opened it and were supposed to let this party in from the back. They were looking for a man in your house in that time of night ([1], p. 17)!" In fact, social workers would often go to extreme lengths to ensure men were absent from the household. Tillmon explains that they would even "pull things out of the washing machine [19]" to check for men's clothes. In this way, aid was intended as a placeholder for a male breadwinner. If a woman had both a male partner and a welfare contract, this compromised her legitimacy as a welfare recipient. Operation Weekend and so-called "man-in-the-house rules" reinforced the common political trope of the absent black father-and in the process, they cast single motherhood as deviant.

Although the US Supreme Court ruled in 1968 that man-in-the-house rules were in conflict with the Social Security Act ([20], pp. 429-31), practices like Operation Weekend still set a pivotal ideological and cultural precedent. Most importantly, they furthered the notion that because welfare mothers were receiving public aid, the government had the right to police their sexual and moral behavior. In other words, rights to privacy were compromised on the basis of race, class, or gender. Premilla Nadasen argues that "under constant scrutiny, recipients had to verify the soundness of their character ([6], pp. 12-13)" - a test to which middle-class or white citizens were seldom subjected. In this way, "caseworkers routinely treated women on welfare like criminals, suspecting immoral behavior, alternate sources of income, and illicit relationships ([6], p. 47)". Race-, gender-, and class-based tropes helped to link welfare with laziness, sexual impropriety, and dishonesty.

These raced and gendered tropes of laziness, promiscuity, and deceit only deepened when Ronald Reagan ran for Governor in 1966. As Annelise Orleck explains, "Conservative critics of the welfare state warned that government aid only encouraged black women's abnormal and irresponsible sexual behavior by providing 'pay for play,' as California governor Ronald Reagan put it in 1966 ([21], p. 86)". At the center of Reagan's platform was a plan for comprehensive, statewide welfare reform. In his inaugural speech to Californians, he pledged to

[restructure] welfare-to eliminate waste and the impropriety of subsidizing those whose greed is greater than their need. The present confusion must be replaced with a program designed to save, rather than destroy, California's greatest resources-its people-a program that will maximize human dignity and salvage the destitute. Here in California nearly a million children are growing up in the stultifying atmosphere of programs that reward people for not working, programs that separate families and doom these children to repeat the cycle in their own adulthood [22].

Note that while Reagan does not explicitly cite race or gender here, he alludes to both with coded language. He invokes images of welfare fraud, an accusation historically levied against black women, by referencing recipients whose "greed is greater than their need" and the welfare programs that "reward people for not working". In this process, Reagan constructs a moral hierarchy. At the bottom of this hierarchy are the "greedy" welfare recipients who feign poverty; at the top are America's "most industrious and self-supporting citizens ([15], p. 279)" — presumably, affluent whites. Reagan managed to partially realize this hierarchy in 1971 with the passage of the Welfare Reform Act.

A compromise between Reagan and several Democratic state legislators, the Welfare Reform Act aimed to decrease state spending for welfare programs. Reagan had hoped for a "closed-end budget" and "ratable reductions" - clauses that would push welfare recipients into employment and guarantee a defined end to benefits. Democrats disagreed, and these measures were struck down. However, new restrictions made qualifying for welfare more difficult ([15], p. 280). This decision reflected Reagan's own belief that mothers on welfare could and should work. Reagan envisioned welfare as "a way-station en route to a permanent job and the dignity of self-sufficiency ([15], p. 280)". For white and affluent women, careers in caretaking and homemaking were acceptable—even encouraged. For 
low-income black women, they were not: instead, these women were often pressured to work outside the home. This pressure did not emerge out of nowhere: in fact, it dates back to the 18th and 19th centuries, prior to the abolition of slavery. As Mimi Abramovitz explains,

The efforts to protect native-born, white women who had to work against the stigma associated with departures from the colonial family ethic did not extend to black women. White society defined and treated black women as laborers rather than homemakers...in the nineteenth century, slave women built levees, laid railroad track, and labored in mines, foundaries, saltworks, sugar refineries, turpentine camps, and food and tobacco processing plants. The practice of slave rental declined once it became less efficient than hiring free labor in the North. Racism and economic necessity forced free black women into the paid labor force ([23], p. 110).

As a result of these practices, one might argue that black women were "proletarianized", reduced solely to their economic value. This legacy hovered over black women-especially welfare recipients-in the 20th century.

In fact, welfare recipients confronted this legacy in their everyday lives. At one CWRO meeting, a welfare recipient shared her daughter's experiences at work. The young woman's boss told her that she "was not eligible for college" and should pursue vocational training instead [12]. At first glance, this may appear to be no more than unsolicited advice. However, underneath the boss's words lies the deeper historical relationship between race, gender, labor, and education. College has historically been understood as time of academic and personal self-discovery-a pursuit only recently extended to women, but even less accessible to low-income and minority women. If welfare recipients or their children sought such "self-discovery", Reaganist logic would cast this as self-indulgence. It should also be noted that local employers-like the one above-were personally invested in maintaining a wage-based workforce. If low-income women left for college, this would leave employers with understaffed businesses. In these ways, the Welfare Reform Act carried a number of implications for black women's labor-and these were felt even in everyday interactions.

Also included in the Welfare Reform Act were new residency restrictions. In order to receive AFDC, recipients in counties with an unemployment rate over $6 \%$ needed to have lived in the same county for at least one calendar year [24]. The CWRO challenged this in court, and it was eventually struck down [24]. Nonetheless, its proposition alone had racial implications, especially for migrants, who were disproportionately black and Latino.

As Reagan had hoped, the welfare rolls began to shrink after the passage of the Welfare Reform Act. Journalists and political analysts attributed the immediate 3\% drop in welfare recipients to declines in unemployment, "a greater emphasis on family planning and abortion", "[h]igher social security payments", "and tougher eligibility rules [25]". The law's mention of family planning hints at stereotypes of black women's hyper-sexuality and hyper-fertility. As Tillmon points out, recipients were often accused of having more children to receive additional money. As Tillmon explained in a magazine article for Ms., "People still believe that old lie that AFDC mothers keep on having kids just to get a bigger welfare check. On the average, another baby means $\$ 35$ a month-barely enough for food and clothing [26]". The last clause, "tougher eligibility rules", helps explain why the welfare rolls shrunk. After the act was passed, fewer people were on welfare-not because they no longer needed it, but because they failed to meet the new residency requirement, or could not become self-sufficient quickly enough. In other words, a decrease in the welfare rolls did not mean a decrease in need for welfare. Moreover, even as total welfare use declined, the proportion of white welfare recipients increased [25]. This demonstrates that the Welfare Reform Act-and its new eligibility restrictions-had varying impacts across race. While white recipients could remain on the rolls, many recipients of color were newly disqualified under the residency restrictions or other clauses.

Much of the anti-welfare legislation and attitudes described above came from white politicians: Governor Reagan, his staff, and the California Legislature. These bodies helped establish Operation 
Weekend, pass the Welfare Reform Act, and in the process, craft new stereotypes about welfare recipients. It should be noted, however, that even some in the middle-class black community held negative beliefs about welfare and its recipients. Low-income black women felt this stigma daily. As Johnnie Tillmon recalls,

When I was working, I had to go to that job on public transportation-you know, the bus. I used to hear the older women and some were black and some were white, who also worked. Maybe they worked in private homes, or as maids in hotels. I used to hear their conversations about welfare mothers. They spoke of them in general as some lazy, shiftless women. Most of these older working women-rather, they called themselves homeowners-were paying on a house, you know, and the taxes were high, so they complained about their high taxes, and how that money was being used for women who had babies just to get another welfare check...I remember when I first used to get my check, I didn't want anybody to know about it. A lot people will do that, now. They don't want people to know that they are getting the money, and they kind of ease the check in the window to be cashed. They look around to see if they know anybody [1].

In Tillmon's recollection, a few things are clear. Most immediate is the salience of class: note that during these uncomfortable bus rides, black women joined white women in maligning welfare recipients. After routinely hearing this language, women on welfare began to internalize it: sneaking checks into bank tellers' windows, and checking to ensure they would not run into friends on the way to the welfare office. This internalized racism and classism was the fault not only of politicians, but also of black community members - men and women alike-who made an effort to distance themselves from their low-income counterparts.

Like some members of the middle class, some liberal white feminists held negative views about welfare and its recipients. For example, some in the National Organization for Women (NOW) supported the nationwide Work Incentive Program, or WIN Program. Passed in 1967, the WIN Program gave job training and eventual employment to welfare mothers. In 1971, however, the program became mandatory for all mothers with children above preschool age ([14], p. 31). NOW helped lobby for this change, much to the dismay of welfare recipients. Catherine Jermany was clearly aggravated:

I was in welfare rights and here is all these women out there trying to do me a favor or do all welfare recipients a favor by protesting and demanding an expansion of the WIN program and wanting everybody to referred [sic] to WIN program regardless of whether or not their children were under 6 or over 6 ...NOW had a demonstration in front of the department of labor in order to expand the WIN program-I mean to expand workfair [sic] in its repressive-its most repressive way [27].

Jermany was not alone in feeling this way. In fact, the vast majority of welfare activists disagreed with the WIN program—so much so, that they jokingly called it “WIP", pronounced 'whip' ([4], p. 97). Though this exchange cannot tell the entire story of NOW's relationship to welfare rights, it does illustrate the political position white feminists occupied relative to their working-class and nonwhite counterparts. Mandatory work programs like WIN implied that housework was illegitimate labor, but only for low-income and minority women. It was largely acceptable, meanwhile, for white or affluent women to refuse employment and remain at home. Many welfare recipients, Jermany included, criticized white feminists for indulging and reinforcing this double-standard.

\section{Welfare Recipients Respond}

Faced with formal opposition by the California government-and informal opposition by some middle-class people and white women-welfare-rights activists were spurred to action. One of the most immediate ways they challenged anti-welfare ideology was by emphasizing childcare-and, in 
the process, suggesting alternate ways of black motherhood. Within ANC-MA, for example, a number of community projects helped to give black women, particularly single mothers, new mobility in their careers and parenting. In 1974, a group of six welfare recipients founded a childcare center, which they named for Johnnie Tillmon. At the center of this project was Mollie Taylor, the center's primary supervisor. According to Taylor, the Tillmon Center gave children "a positive ethnic identification and a potential to succeed at their own pace [28]". By fostering a positive racial self-image in young children, the Tillmon Center and spaces like it provided a counter-narrative to dominant messaging about the black poor. It also allowed welfare mothers to pass their activist ideology on to the next generation. The Tillmon Center was accessible to all parents, regardless of ability to pay [28]. Amid racialized comments by politicians, the Tillmon Center offered a space for positive racial messaging. It should also be noted that in the 1960s and 70s, paid childcare was a luxury of white affluent mothers-who, ironically, often hired black women to watch their children. The Tillmon center allowed working black mothers to share in this same privilege. These mothers no longer needed to choose between adequate wages and adequate childcare: a decision the state often forced them to make under programs like WIN.

The CWRO placed a similar emphasis on childcare. Following the Welfare Reform Act, the CWRO filed a lawsuit against state welfare director Robert B. Carleson, because he was not sufficiently enforcing "the expanded child care provisions of the Welfare Reform Act of 1971 [29]". Catherine Jermany, President of the CWRO, defended their decision to file suit. She argued, "Working welfare mothers have tremendous need for child care since most of them are working at low wages, and the absence of adequate childcare can, in itself, completely prevent them from accepting employment [29]". By explaining this reality, Jermany illustrated the hypocrisy of a welfare state that pressured recipients into employment but made parentally responsible, living-wage employment extremely difficult. This was a basic fact: without affordable and convenient childcare, no mother on welfare would leave home for a low-wage job.

Welfare-rights activists also challenged reigning attitudes on welfare in their own racial communities. When middle-class black Californians seemed to indulge Reaganist welfare ideology, Catherine Jermany was not afraid to rebuke them. In her 1962 article, "Message to the Black Social Worker", she criticizes them for abandoning their working-class counterparts. She tells black social workers, "As you all know, the system you work for is racist...The man has given you a job, and told you that you were middle class-HA, HA you are just one set of SLAVES to rule another set of SLAVES - and don't you forget it ([30], p. 3)!" Here Jermany hints at and subverts an intra-racial class hierarchy-one as old as the distinction between "house" and "field" slave. She closes her letter with an appeal: "I know you have to work and need your job-I am not asking you to quit now-I am asking you to do whatever is necessary in your agency for your Black Clients so that they can benefit from your existence. If you can not or will not your existence in the Black community is invalid ([30], p. 3)." Jermany shows black professionals not just the tenuous nature of their position, but also the reality that their success depends on the marginalization of a less powerful group: welfare recipients.

In part, this intra-racial hierarchy stemmed from the hegemony of the nuclear family. Middle-class, two-parent heterosexual households were valorized as the ideal family structure, with little regard for alternate family types. Welfare mothers, who tended not to come from these households, challenged this notion. In fact, many welfare mothers believed nuclear families and biological parenting were irrelevant to family upbringing and quality of life. Tillmon shared in that belief. In a 1991 interview, she reflected on her upbringing in rural 1930s Arkansas. She explained, "As black folks, we had extended families. And if you took care of me, I could take your name. I became yours. No adoption, no papers, none of that kind of stuff. Nobody questioned that, nobody criticized, the child was loyal, the child had a roof over his head, and you treated the child like your own. The laws came in and got rid of all of that [19]." In describing her personal values, Tillmon suggested something quite counterhegemonic: that in a family, biological parenthood has little to no intrinsic value. Tillmon also suggested that her approach was a product of race, class, and culture. Later, that approach was threatened by "the laws", 
"papers", and other formalities the legislature-a predominantly white body-established. In this way, she positioned the biological family as a white imposition: one with little relevance to black families.

If biological parenthood meant little to Tillmon, single motherhood did too: it had no fundamental bearing on a child's wellbeing or a mother's parenting abilities. Amid attempts by lawmakers and mainstream press to pathologize single motherhood, Tillmon emerged as a dissenting voice. She challenged the popular notion that single-parent, female-headed families were incomplete. Herself a single mother, Tillmon believed her children missed nothing in growing up without a father. In 1991, historian Sherna Gluck told Tillmon that "some [divorced or widowed] women said they needed to remarry for economic reasons". She asked Tillmon if she ever felt similarly. Tillmon said no: "My children wasn't any hungrier than theirs. I have never depended on nobody like that. I was raised to be an independent person [19]." Moreover, Tillmon found her marriage constraining. She believed that had she not divorced her husband, she would not have become the activist she eventually became. As eventual chair of the NWRO, Tillmon traveled globally to examine other nations' class struggles-something her first husband would not have allowed her to do [19]. In recounting these experiences, Tillmon demonstrated that there was nothing inappropriate, neglectful, or deviant about single motherhood. In fact, her words even suggest that for some women, single motherhood might be ideal for the autonomy and mobility it affords.

Because single mothers like Tillmon played both breadwinner and caretaker, they often divorced parental responsibilities from their gendered connotations. As Tillmon looked back on her childhood, she said, "I done for my children what my father done for me": she fed them, clothed them, and funded their educations [19]. Because her father once filled this role-and she, too, filled this role for her own children-caretaking and breadwinning almost lost their gendered character. In her 1991 interview, Tillmon proudly listed her children by name. All were adults with non-domestic careers [19]. This trajectory might suggest that Tillmon grew up in a less gender-rigid environment, raised her own children in this way, and they, too, maintained this philosophy in their professional lives.

Of course, Tillmon was not the only welfare-rights activist who challenged rigid gender roles. Under the auspices of the CWRO, a number of welfare-rights activists took on rigid gender roles in the form of lawsuits. In many of these cases, the activists' main target was Robert B. Carleson. Carleson had a bad reputation with the welfare-rights community: he was Governor Reagan's appointed welfare policy advisor, and he helped to craft the Welfare Reform Act [31]. In 1971, welfare-rights activists, with the help of some Bay Area legal groups, challenged a clause of the Welfare Reform Act Carleson designed, which stated that "half the earnings of a stepfather of an AFDC family shall be counted as available income for support of the family [32]". By including the stepfather's earnings in the calculation of available income, the California government could shrink welfare mothers' checks, or cancel them altogether. This clause assumed any man would take responsibility for his partner's children-regardless of paternity. In this way, the clause attempted to cure the so-called pathology of the black matriarch by forcing her into a traditional, two-parent family structure. This did not go unnoticed by welfare mothers in California, who had to sit and watch as investigators rifled through their things, searching for any signs of a boyfriend. The CWRO challenged the clause on the basis that it was unrealistic - but they also challenged it for its gendered and racial implications.

Other welfare-rights activists challenged gendered notions of power and success. Espanola Jackson was asked by Guida West, “How do you feel about-black men going up for president or a woman going up for president or vice president or something?" Jackson responded not with a 'yes' or 'no', but instead said, "I feel that I could be the president. I don't have no problems. I think I would have more to give and what I've seen because of the fact of how I've lived I've lived poor and I've lived good and I'm not living bad now [8]." At first glance this moment seems trivial, as the presidency may not be the most indicative measure of social change. However, West's mention of "black men" and "women" presumes a certain dichotomy, wherein the hypothetical man is black and hypothetical woman is white. By inserting herself in this hypothetical, Jackson disrupts this dichotomy and reifies the possibility of an intersectional black women's politics. As Frances Beale points out, this is no small 
feat, because women's liberation movements have historically adopted a white character, while black liberation movements have historically centered men's interests. Moreover, as Frances Beale points out, black women have sometimes been valued only insofar as they can reproduce for "the Black Nation ([33], p. 113)". Jackson counters this notion by making clear her political and ideological value to black struggles, feminist struggles, and even the nation's collective future.

Amid all the legislation, debates, and tropes that hovered in the American and Californian consciousness about welfare, actual welfare recipients were often silenced. Many people knew only of the figurative, invented "welfare queen" —not Espanola Jackson, Catherine Jermany, Dee Johnson, or Johnnie Tillmon. These activists exploded those tropes, and they continued organizing through the 1970s. Though the NWRO went bankrupt in 1973 ([4], pp. 180-81), this did not spell the end of the movement. New changes in welfare policy would later demand activists' attention. In 1996-just after Johnnie Tillmon's death-AFDC was discontinued under President Clinton and replaced with a more punitive system: Temporary Assistance to Needy Families ([34], p. 62), or TANF. In response, welfare-rights activism resurged on the local level. Some state organizations, like the Michigan Welfare Rights Organization (MWRO), had never left the scene. The MWRO was formerly an NWRO chapter and still uses the NWRO logo [35]. Other organizations, like the Coalition of California Welfare Rights Organizations, emerged later, after the NWRO's closure [36].

Today, politicians continue to raise the specter of welfare dependency and fraud-even though the number of welfare recipients nationwide has declined since 1996 [37]. While campaigning for the Republican presidential nomination in 2012, former Senator Rick Santorum told an Iowa crowd, "I don't want to make black people's lives better by giving them somebody else's money; I want to give them the opportunity to go out and earn the money [38]." In February 2017, Donald Trump told the Conservative Political Action Conference, "It's time for all Americans to get off of welfare and get back to work [39]." These comments clearly recycle the racialized tropes with which Johnson, Jermany, and many other activists were all too familiar. As Moiece Palladino points out, however, it is when groups of marginalized people organize that they threaten not just punitive policy, but also its underlying logics. She told Guida West:

I think the thing that I want to highlight about welfare rights is the ability of women working together to see themselves not as powerless in the system...Women are told in some family structures that they're not good. That...if you're on welfare you're bad, there's something wrong with you as a person and I think that's reinforced in a dozen different ways every day, every time you use your food stamp card, every time you use your [unclear] card, every time you get on the bus with a discount card you are reinforced by the look of the person in his face there is something wrong with you and that if welfare gave me nothing else it gave me the feeling that I'm not only ok but I'm a decent caring human person and that I have the ability and capacity that's the same and equal to any other person in this society and that if I can take some power over my life then I can effect some changes and that I need not be subject to those whims just because they're blowing in whatever direction. That I'm the one who makes that determination [9].

In emphasizing childcare, challenging middle-class complacency, and dismissing rigid gender roles, welfare-rights activists chipped away at one of the most basic assumptions of American politics: the notion that shame must accompany poverty. This is a notion that economic-justice activists, decades after this movement, still resist today.

Acknowledgments: This research was completed with financial support from the Mellon Mays Undergraduate Fellowship and Office of Undergraduate Advising and Research at Dartmouth College.

Conflicts of Interest: The author declares no conflicts of interest. 


\section{Abbreviations}

The following abbreviations are used in this manuscript:

$\begin{array}{ll}\text { AFDC } & \text { Aid to Families with Dependent Children } \\ \text { ANC-MA } & \text { Aid to Needy Children-Mothers Anonymous } \\ \text { CWRO } & \text { California Welfare Rights Organization } \\ \text { FAP } & \text { Family Assistance Plan } \\ \text { MWRO } & \text { Michigan Welfare Rights Organization } \\ \text { NOW } & \text { National Organization for Women } \\ \text { NWRO } & \text { National Welfare Rights Organization } \\ \text { TANF } & \text { Temporary Assistance to Needy Families } \\ \text { WIN } & \text { Work Incentive Program }\end{array}$

\section{References and Notes}

1. Johnnie Tillmon, and Hobart Burch. "Insights of a Welfare Mother: Conversations with Johnnie Tillmon." The Journal 14 (1970): 13-23. Box 30, Folder 5, George Wiley Papers, Wisconsin Historical Society, Madison.

2. List of Welfare Rights Organizations in California. Box 8, Folder 2, George Wiley Papers, Wisconsin Historical Society, Madison.

3. Ellen Reese, and Garnett Newcombe. “Income Rights, Mothers' Rights, or Workers' Rights? Collective Action Frames, Organizational Ideologies, and the American Welfare Rights Movement." Social Problems 50 (2003): 294-318. [CrossRef]

4. Felicia Kornbluh. The Battle for Welfare Rights. Philadelphia: University of Pennsylvania Press, 2007.

5. Dee Johnson. Transcript. Interviewed by Guida West. Box 8, Folder 9, Guida West Papers, Sophia Smith Collection, Smith College, Northampton, 2 April 1984.

6. Premilla Nadasen. Welfare Warriors: The Welfare Rights Movement in the United States. New York: Routledge, 2005.

7. Johnnie Tillmon to NWRO Executive Board. Box 8, Folder 1, George Wiley Papers, Wisconsin Historical Society, Madison, 2 December 1971.

8. Espanola Jackson. Transcript. Interviewed by Guida West. Box 7, Folder 24, Guida West Papers, Sophia Smith Collection, Smith College, Northampton, 4 April 1984.

9. Moiece Palladino. Transcript. Interviewed by Guida West. Box 9, Folder 21, Guida West Papers, Sophia Smith Collection. Smith College, Northampton, 5 April 1984.

10. “The Family-Assistance Plan: A Chronology." Social Service Review 46 (1972): 603-8.

11. California Welfare Rights Organization. Press Release. Box 24, Folder 13, George Wiley Papers, Madison, Wisconsin Historical Society, 23 June 1971.

12. California State Welfare Rights Organization: State Meeting. Box 24, Folder 13, George Wiley Papers, Wisconsin Historical Society, Madison, 18 January 1969.

13. Sharon Hays. Flat Broke With Children: Women in the Age of Welfare Reform. New York: Oxford University Press, 2003.

14. Susan W. Blank, and Barbara B. Blum. "A Brief History of Work Expectations for Welfare Mothers." The Future of Children 7 (1997): 28-38. [CrossRef] [PubMed]

15. Garin Burbank. "Governor Reagan and California Welfare Reform: The Grand Compromise of 1971." California History 70 (1991): 278-89. [CrossRef]

16. Joanne Goodwin. "'Employable Mothers' and 'Suitable Work': A Re-Evaluation of Welfare and Wage-Earning for Women in the Twentieth-Century United States." Journal of Social History 29 (1995): 253-74. [CrossRef]

17. Guida West. “Women in the Welfare Rights Movement: Reform or Revolution?" Dialectical Anthropology 15 (1990): 141-49.

18. Bernadette J. Brooten. Beyond Slavery: Overcoming its Religious and Sexual Legacies. New York: Palgrave Macmillan, 2010.

19. Johnnie Tillmon. Recording. "Welfare Mothers, Welfare Rights." Interviewed by Sherna Gluck. Collection, Virtual Oral/Aural History Archive. Long Beach: California State University at Long Beach, February 1984. Available online: http:/ / symposia.library.csulb.edu/iii/cpro/CollectionViewPage.external?lang=eng\&sp= 1000076\&suite $=$ def (accessed on 11 July 2014). 
20. William P. Croke. “Poverty Law: King v. Smith and 'Man-In-The-Home'." Marquette Law Review 52 (1969): 422-31.

21. Annelise Orleck. Storming Caesars Palace: How Black Mothers Fought Their Own War on Poverty. Boston: Beacon Press, 2005.

22. Ronald Reagan. "Inaugural Address." 4 January 1971. Gubernatorial Speeches Collection, Ronald Reagan Presidential Library \& Museum. Available online: https:/ / reaganlibrary.archives.gov/archives/speeches / govspeech/01041971a.htm (accessed on 20 July 2014).

23. Mimi Abramovitz. Regulating the Lives of Women: Social Welfare Policy from Colonial Times to the Present. Boston: South End Press, 1988.

24. "California Residency Law Void." The Welfare Fighter, 21 July 1970.

25. Michael Harris. "State Welfare Rolls Are Down—by 2 Yardsticks." San Francisco Chronicle, 2 February 1972. Box 15, Folder 1, George Wiley Papers. Madison: Wisconsin Historical Society.

26. Johnnie Tillmon. Welfare Is a Women's Issue. Ms., Box 36, Folder 9, George Wiley Papers, Wisconsin Historical Society, Madison, Spring 1972.

27. Catherine Jermany. Transcript. Interviewed by Guida West. Box 8, Folder 6, Guida West Papers, Sophia Smith Archive. Smith College, Northampton.

28. Carl Coates. "Child Care Center Opens." Los Angeles Sentinel, 7 November 1974.

29. "The States Report." The Welfare Fighter, 21 July 1970.

30. Catherine Jermany. "Message to the Black Social Worker." LA County Welfare Rights Newsletter 1 (1962): 1, 3, 6.

31. Dennis McLellan. "Robert B. Carleson, 75; Pioneered Welfare Reform under Reagan in California, U.S." Los Angeles Times, 27 April 2006. Available online: http://articles.latimes.com/2006/apr/27/local/mecarleson27 (accessed on 2 August 2014).

32. "Welfare Reform Act Comes Under Heavy Attack in State and Federal Courts." California Journal, October 1971. Box 24, Folder 13, George Wiley Papers, Wisconsin Historical Society, Madison.

33. Frances Beale. "Double Jeopardy: To Be Black and Female." In The Black Woman: An Anthology. Edited by Toni Cade Bambara. New York: New American Library, 1970.

34. Cristina Gallo. "Marrying Poor: Women's Citizenship, Race, and TANF Policies." UCLA Women's Law Journal 19 (2012): 61-116.

35. Michigan Welfare Rights Organization: The Union for Public Assistance Recipients and Low Income People. Available online: http:/ / mwro.org/ (accessed on 14 March 2017).

36. Coalition of California Welfare Rights Organizations, Inc. Available online: http:/ / ccwro.org/ (accessed on 14 March 2017).

37. Paul Davidson. "Can Trump Get More Welfare Recipients Back to Work?" USA Today, 2 March 2017. Available online: http:/ /www.usatoday.com/story/money/2017/03/02/can-trump-get-more-welfarerecipients-back-work/98603820/ (accessed on 15 March 2017).

38. Lucy Madison. "Santorum Targets Blacks in Entitlement Reform." CBS News, 2 January 2012. Available online: http:/ /www.cbsnews.com/8301-503544_162-57350990-503544/santorum-targets-blacksin-entitlement-reform/ (accessed on 15 March 2017).

39. Tessa Berenson. "CPAC: President Trump Says 'It's Time for Americans to Get Off of Welfare." Time, 24 February 2017. Available online: http:/ / time.com/4682003/donald-trump-cpac-welfare/ (accessed on 15 March 2017).

(c) 2017 by the author. Licensee MDPI, Basel, Switzerland. This article is an open access article distributed under the terms and conditions of the Creative Commons Attribution (CC BY) license (http:/ / creativecommons.org/licenses/by/4.0/). 